\title{
THE INTERNATIONAL CRIMINAL COUR', AGGRESSION, AND OTHER MATTERS: A RESPONSE TO KOH AND BUCHWALD
}

\author{
Nicholas Rostow*
}

\section{Introduction}

This essay, stimulated by themes discussed by Harold Koh and Todd Buchwald, examines the International Criminal Court (ICC) and the amendment to the 1998 Rome Statute to include the crime of aggression within the ICC's jurisdiction. The definition adopted in Kampala in 2010 is too long to quote in full but merits careful examination. For example, it states that the "crime of aggression' means the planning, preparation, initiation or execution, by a person in a position effectively to exercise control over or to direct the political or military action of a State, of an act of aggression which, by its character, gravity and scale, constitutes a manifest violation of the Charter of the United Nations."1 It then adopts large swaths of UN General Assembly Resolution 3314 (XXIX) of 1974 - the definition of aggression—as its own. ${ }^{2}$ Commentators recognized problems with the 1974 definition at the time. ${ }^{3}$ The post-Kampala Rome Statute purports to achieve objectivity with respect to aggression through removal of everything having to do with context and the totality of the circumstances. These matters surely should be - and must be_of central importance not only to nonparties but also to the parties to the Rome Statute. The fact that they are absent forms the raison d'etre of this essay. Because the ICC is a permanent body, able to take jurisdiction of ongoing problems, its actions may have significant implications for world public order.

\section{The UN System of Minimum Order}

Observed from outer space, Earth appears without boundaries or human characteristics until approached or viewed through a high-powered telescope. Up close, all the human creations appear, towns, farms, and countries. Once having landed, the outer-space observer would come to see and understand the absence of world government. Rather, the world is organized into states that have combined in international organizations to which they have delegated powers for certain purposes. This structure reflects centuries of historical experience with different governance models. Governments rejected all the alternatives because they failed what became the most important test of effective international relations, the prevention or avoidance of general war among

* Charles Evans Hughes Visiting Professor of Jurisprudence and Government, Colgate University.

Originally published online 02 March 2016.

${ }^{1}$ Rome Statute of the International Criminal Court art 8bis, July 17, 1998, 2187 UNTS.

2 W. Michael Reisman, Reflections on the Judicialization of the Crime of Aggression, YALE J. INT'L L. ONLINE (Spring 2014) and Harold Hongju Koh \& Todd F. Buchwald, The Crime of Aggression: The United States Perspective, 109 AJIL 257 (2015) note how the Kampala Conference changed the meaning of the 1974 Definition of Aggression with the result that the Kampala version is even more problematic than the original.

${ }^{3}$ See Julius Stone, Conflict Through Consensus: United Nations ApproAChes to Aggression (1977). 
the great powers. This purpose overrode all others because the costs of such general war demonstrably were too large to tolerate, especially in a world of nuclear weapons. The result is the structure of today's world.

A feature of that structure is the sometimes uneasy marriage of politics and law. The UN Charter, for example, codified the most important rules of international conduct, ${ }^{4}$ established organs charged with responsibility for maintaining international peace and security within the limits of reality, and created an international organization that has grown in size and complexity. ${ }^{5}$ The relationship between law and politics is of heightened importance in the UN system because the institution owes its existence to the conviction that law can and must buttress the peace. It should harness power, not pretend power is unimportant. Therefore, the law can inform political judgment and decision but not substitute for them.

Our space traveler also would see that the international system values structural flexibility. Continuously operating centripetal and centrifugal forces bring states closer together and drive them farther apart, simultaneously strengthening the opposite desires for international institutions and collaboration and for exclusive local control. In addition, of course, nonstate actors-nongovernmental organizations, citizen organizations, corporations, and terrorists, just to name the most obvious - complicate the context of international and national decision-making and contribute to such centripetal and centrifugal forces. The complexity of international reality makes the job of international criminal judge more, not less, difficult than would be the case in any event.

Within this structure, the space traveler comes to understand that norms and expectations have developed, reinforcing the historical pattern of coalitions of states balancing overweening individual states. That balancing is in fact the balance of power in action and the law of the system. The balancing hinders those states that seek mastery through war-Louis XIV, Napoleon, Wilhelm II, and Hitler, for example-and even obstructs the efforts of any would-be managers of the international system, as Bismarck himself discovered in 1875 and, some argue, the United States since the end of the Cold War. Because of their destructiveness, the great world wars generated progress toward a global, structured regime of collective security, which the persistent balancing process represents.

As the UN Charter itself shows, the current form of this regime is not world government. The right of individual or collective self-defense persists despite a general prohibition on the threat or use of force and the assignment to the UN Security Council of primary responsibility for the maintenance of international peace and security. As a result, the balance of power has remained the most fundamental of international law's planks. More than fifty years ago, Martin Wight noted, "[t]he alternatives to the balance of power are either universal anarchy or universal dominion. A little reflection will show that the balance of power is preferable to the first; and we have not yet been persuaded that the second is so preferable to the balance of power that we shall submit to it."6 Wight's insight plays out when nonpermanent members of the United Nations conclude that the Security Council is exercising a form of "universal dominion" and legislating for the world although the Council only has fifteen members. ${ }^{7}$ Yet, the existence of the Security Council was a response to the failure of

${ }^{4}$ UN Charter arts. 2(4) (prohibition on threat or use of force), 51 (inherent right of self-defense affirmed).

${ }^{5}$ It makes and has its own reality. See Hernane Tavares de SÁ, The Play Within the Play: The Inside Story of THe UN (1966).

${ }^{6}$ Martin Wight, Power Politics $184-85$ (by Hedley Bull \& Carsten Holbraad eds., 2d ed. 1986).

${ }^{7}$ Nonpermanent members of the Security Council such as Germany and Pakistan came to see Security Council Resolution 1373 (2001), the sweeping counter-terrorism resolution adopted after September 11, 2001, and Resolution 1540 (2004), which addressed the problem of the proliferation of weapons of mass destruction and their delivery systems to nonstate actors, as examples of Security Council overreach. See the statements at the Security Council's open meeting on April 22, 2004. Security Council, Meeting Record, $4950^{\text {th }}$ meeting, UN Doc. S/PV.4950 (Apr. 22, 2004), and Security Council, Meeting Record, $4950^{\text {th }}$ meeting, Resumption 1, UN Doc. S/PV.4950 (Resumption 1) (Apr. 22, 2004). See also, Eric Rosand, The Security Council as “Global Legislator": Ultra Vires or Ultra Innovative?, 28 Fordham INT'L L.J. 542 (2004). 
the League of Nations to provide for any institution that brought together most of the military and economic power in the world with an executive character able to take decisions, binding on all states, with respect to the maintenance of international peace and security. Nothing in the period since 1945 suggests that, however flawed the record of the Security Council, the General Assembly or any other international body, including the International Criminal Court, would do better were it empowered to maintain the peace.

Under the UN Charter, world order is minimum. It rests on the principle that states shall refrain from the threat or use of force against the territorial integrity or political independence of any state. Of all the norms of the Charter this one, enshrined in Article 2(4), is fundamental, indeed essential. Every other limit on the international behavior of states follows from it. Whether the ICC deals with aggression in a manner consistent with this minimum order context is a question whose significance is difficult to underestimate.

\section{Enter the Judicial Power}

The effort to contain conflict, whether inter- or intrastate, involves skill, endurance, compromise, and luck. The framers of the UN Charter recognized the importance of suppressing aggression and granted the UN Security Council apparently dispositive power and responsibility effectively to determine whether aggression has taken place as part of its primary responsibility for maintaining international peace and security. ${ }^{8}$ In doing so, they accepted that the treatment of aggression was among the most important and most sensitive issues. They recognized that the decision that aggression had occurred was a political as much or even more than a moral or legal issue. Indeed, they had lived with the consequences of mistaken action in this regard. Whatever one's view of responsibilities for World War I, blaming Germany in the Treaty of Versailles was foolishness of huge consequence. The fact that the UN Security Council routinely has been reluctant to name an aggressor is evidence of the power of that lesson and the sensitivity of the problem: once done, it is hard to compromise.

What is there to negotiate about once one has determined that a state has committed aggression and its leaders are guilty of the crime of aggression? After Waterloo, the victorious powers determined that Napoleon was an enemy of peace and an outlaw. They agreed to dispatch him to St. Helena. They did not bother with a trial. It served a moral purpose, perhaps, for the League of Nations officially to name the Soviet Union an aggressor for attacking Finland in 1939. The gesture did not prove to be a statement of international opprobrium that had consequences that mattered. Would it have advanced any cause at all to name Egypt, Jordan, and Syria aggressors for attacking Israel? Even the UN Security Council did not find North Korea to have committed aggression rather than an "armed attack" — a much more neutral term—in June 1950.

Words matter and have consequences, foreseen and unforeseen. The maintenance of peace is not a matter of feeling good. Determinations of aggression are political and rightly so. The U.S. government has accused Russia of aggression against Ukraine, only to find Russia a necessary partner in the Middle East. Alain Pellet accuses the United States and its partners of aggression against Iraq in 2003.9 Apart from the fact that Russia and the United States and its partners take a different view, what would it achieve for the ICC to make such a finding? Or to conclude the other way? Would any ICC decision contribute to sorting out the dangerous chaos in the Middle East, for example?

Is an ICC determination that leaders of Country A have committed aggression and should be jailed likely to deter? In the past, the risk of defeat, surely a worse punishment for an aggressor, has not been a deterrent. And

${ }^{8}$ UN Charter arts. 1(1), 39, 24(1).

${ }^{9}$ Compare Allain Pellet's assertions on the subject, Alain Pellet, Response to Koh and Buchwald's Article: Don Quixote and Sancho Panza Tilt at Windmills, 109 AJIL 557 (2015), with William H. Taft IV \& Todd .F. Buchwald, Preemption, Iraq, and International Law, 97 AJIL 557 (2003) and Nicholas Rostow, Determining the Lawfulness of the 2003 Campaign against Iraq, 34 IsR. Y.B. HuM. RTs. 15. Legality, of course, is not the same as wisdom. 
is a court, any more than any other body, "objective" in its application of the law? 10 The most that can be hoped from a court is reasoned application of the law and consistency with precedent. In a democratic society there are democratic checks on courts. In adopting the language of Article 39, "[ $[\mathrm{t}$ he Security Council shall determine the existence of any threat to the peace, breach of the peace, or act of aggression," the framers of the UN Charter gave the Council flexibility and power. The Charter invited appraisal, assessment, and judgment, not rigidity and automaticity in discharging the Council's responsibilities. In so doing, the Charter encourages compromises essential to peace. If one-size-fits all fails to assist societies emerging from conflict and seeking transitional justice, ${ }^{11}$ all the more does one size not fit all when trying to decide if aggression has taken place and what state is responsible. Even the judicial process requires judgment: one-size-fits-all is the starting point for judicial decision. From it, judges begin to make distinctions. For this reason alone it likely is not going to prove helpful to grant the ICC jurisdiction over aggression, much less to apply the anticontextual definition of aggression adopted by the States Parties to the Rome Statute. The 1974 definition, however much it is open to criticism, offered guidance to the Security Council and noted the importance of "other relevant circumstances" to be considered in any determination whether aggression has occurred. Often, countries understand that what needs to be done may not conform exactly to what some other countries might regard as black letter law. The Kampala amendments deviated from this contextual approach, thus raising more questions than they answered. ${ }^{12}$

\section{Conclusion}

My conclusion is easy to state: the ICC is too significant an institution and the issues its very existence raises are too important to be left to lawyers and law professors. ${ }^{13}$ Most governments and nongovernmental organizations, including the United Nations, let the legal experts do most of the running. They may or may not present the full range of political and military considerations involved in every ICC action that their policy clients would want to consider. One knows that law-abiding people will try to obey the law. One knows equally that criminals will not. One does not want to create incentives for the criminal class of statesmen to act according to their nature.

The stakes therefore are high and seem to affect the character of world public order. The choice of "seem to" is deliberate: some who participated in negotiating the Kampala amendments believe that it did and should change that character. The ICC does not just look backwards, after the dusts kicked up by war, conflict, and politics have settled. It can and does act in the middle of the fray, when facts are hardest to know, the hierarchy of values and interests may be difficult to discern, and the weighing of competing interests in progress. This

\footnotetext{
10 Of the examples one could cite to illuminate the point that objectivity is illusive, the 2005 report on Darfur of the International Committee of Inquiry is notable. The Commission concluded that genocide had not occurred in Darfur because the fact that humanitarian assistance was delivered to the victims of government policy showed a lack of the requisite mens rea on the part of the Sudanese government. The Commission ignored the fact that the Sudanese government had not intended that such assistance be provided and permitted it only under intense international pressure, including the imminence of international peacekeeping missions and visits by UN and other officials. Rather, the Commission devoted most space to urging a UN Security Council referral to the ICC. It achieved its goal. Int'l Comm'n of Inquiry on Darfur, Report to the Secretary-General (Jan. 25, 2005).

${ }^{11}$ Security Council, Meeting Record, 4833rd Meeting, UN Doc. S/PV. 4833 (Sep. 24, 2003) (then Secretary-General Kofi Annan said that one size did not fill all cases in matters of transitional justice although he did state that one should not compromise with some crimes such as genocide).

12 Koh \& Buchwald, supra note 2, at 267; Reisman, supra note 2, at 69-73.

${ }_{13}$ Compare Bing Bing Jia, The Crime of Aggression as Custom and the Mechanisms for Determining an Act of Aggression, 109 AJIL 569 (2015) with Alain Pellet, supra note 9 .
} 
fact alone makes it likely that jurisdiction over aggression will result in the ICC taking sides in an ongoing conflict.

One may expect ICC indictments for aggression to have far-reaching consequences. One may anticipate that an international indictment against a state's leaders in the middle of conflict on the basis of definitions the content of which is political will have effects having little to do with justice. Its enforcement may increase violence, conflict, and collateral damage to civilians. The ICC can affect day-to-day politics depending on who wants to use it and how. Reports suggest that the ICC Prosecutor has taken these factors into account in evaluating the costs and benefits of action in considering whether to proceed with respect to allegations of genocide, war crimes, and crimes against humanity. What will happen when she does in cases where the issue is aggression?

The international system brings together law and politics. It leaves the most sensitive assessments to political organs. Their members ought to take law into account. That is different from turning their responsibilities over to a court. Handing those assessments over to judicial process is not free from danger and certainly has consequences, especially for those who must implement the decisions. In the international sphere, that job ultimately can fall to the armed forces. In any event, granting the ICC jurisdiction over aggression inevitably will subject the ICC to criticism that exercising such jurisdiction would be a political act in keeping with the political judgment that aggression has occurred.

One should have no illusions about the consequences of mixing the pursuit of justice in the here-and-now. Political leaders have to hew to the art of the possible in an environment fraught with danger. Arrogating to the ICC responsibility with respect to peace and security - and especially through such notions as a crime of aggression - is inconsistent with the ideas forming the premise of the United Nations. 